\title{
Pengaruh Bauran Pemasaran Jasa dan Citra Merek terhadap Reputasi Penyelenggara Jasa Pendidikan
}

\author{
Lady Diana Warpindyastuti \\ Sistem Informasi Akuntasi, Universitas Bina Sarana Informatika \\ e-mail: lady.lwd@bsi.ac.id

\begin{tabular}{ccc}
\hline Diterima & Direvisi & Disetujui \\
$28-08-2019$ & $27-09-2019$ & $30-09-2019$ \\
\hline
\end{tabular}

\begin{abstract}
Abstrak - Strategi pemasaran diperlukan dalam bisnis apa pun, tidak terkecuali dalam bisnis pendidikan. Tetapi untuk memasarkan sekolah negeri, citra sekolah diperlukan untuk membentuk reputasi sekolah sehingga orang tua tertarik untuk mengirim anak-anak mereka ke sekolah negeri. Madrasah Ibtidaiyah Negeri 18 Jakarta juga mementingkan Bauran Pemasaran Layanan dan Citra Merek untuk membangun reputasinya. Maka tujuan dari penelitian ini adalah untuk mengetahui seberapa besar pengaruh Bauran Pemasaran Layanan dan Citra Merek baik secara terpisah (parsial) maupun secara bersama-sama (simultan) terhadap Reputasi Penyedia Layanan Pendidikan di Madrasah Ibtidaiyah Negeri 18 Jakarta. Penelitian ini menggunakan metode kuantitatif dengan kuesioner 83 sampel dari 480 orang tua siswa di Madrasah Ibtidaiyah Negeri 18 Jakarta. Kemudian, rumus persamaan regresi ditentukan setelah uji validitas, uji reliabilitas, uji normalitas, uji multikolinieritas, heterokedastisitas, dan uji korelasi pada masing-masing hasil kuesioner dan skor untuk variabel dependen dan variabel independen. Hasil penelitian menunjukkan bahwa Bauran Pemasaran Layanan dan Citra Merek secara terpisah dan bersama-sama secara signifikan mempengaruhi Reputasi Penyedia Layanan Pendidikan di Jakarta 18 Madrasah Ibtidaiyah dengan akurasi $99 \%$.
\end{abstract}

Kata kunci: Bauran Pemasaran Layanan, Citra Merek dan Reputasi

\begin{abstract}
Marketing strategy is needed in any business, no exception in the business of education. But for marketing public schools and school image is needed to shape the reputation of the school so that parents are interested in sending their children to the state school. Madrasah Ibtidaiyah Negeri 18 Jakarta also attaches importance to the Service Marketing Mix and Brand Image to build its reputation. So the purpose of this research is to find out how big the influence of Service Marketing Mix and Brand Image both separately (partial) and jointly (simultaneously) on the Reputation of Educational Service Providers in Madrasah Ibtidaiyah Negeri 18 Jakarta. This study uses a quantitative method with a questionnaire of 83 samples from 480 parents of students at Madrasah Ibtidaiyah Negeri 18 Jakarta. Then, the regression equation formula is determined after the validity test, reliability test, normality test, multicollinearity test, heterokedastisitas, and correlation test on each questionnaire results and scores for both the dependent variable and the independent variable. The results showed that the Marketing Mix of Services and Brand Image both separately and together significantly affected the Reputation of Providers of Educational Services in Jakarta 18 Madrasah Ibtidaiyah with 99\% accuracy.
\end{abstract}

Keywords: Service Marketing Mix, Brand Image and Reputation

\section{PENDAHULUAN}

Pendidikan merupakan salah satu upaya manusia untuk memberantas kemiskinan. Sebegitu pentingnya pendidikan sehingga di dalam Pembukaan UUD 1945, tertulis yaitu memajukan kesejahteraan umum dan mencerdaskan kehidupan bangsa. Dalam pasal 31, pendidikan merupakan hak setiap warga negara indonesia. Pelaksanaan pendidikan diselenggarakan melalui Sistem Pendidikan Nasional. Salah satu wujud dari penyelenggaraan pendidikan nasional adalah penyelenggara jasa pendidikan swasta. Tumbuhnya penyelenggara jasa pendidikan swasta menimbulkan persaingan yang ketat untuk mendapatkan konsumen.
Dengan adanya persaingan yang sangat ketat ini, menempatkan pemasaran jasa pendidikan sebagai ilmu yang terpenting.

Lembaga pendidikan adalah sebuah kegiatan yang melayani konsumen berupa siswa dan masyarakat umum yang dikenal dengan stakeholder. Pada hakikatnya, suatu lembaga pendidikan bertujuan memberikan suatu pelayanan dan pihak yang dilayani menginginkan kepuasan dari pelayanan tersebut. Oleh sebab itulah lembaga pendidikan perlu memperhatikan reputasi dari organisasinya sehingga dapat memenangkan persaingan.

MIN 18 Jakarta adalah salah satu sekolah dasar yang bernafaskan agama Islam yang berada dibawah 
naungan Departemen Agama Republik Indonesia. Madrasah ini berdiri pada Tahun 2007 dan pada tahun itu juga dapat dioperasikan dengan nama MIN Kalisari yang masih menginduk di MIN Cijantung. Alamat MIN 18 Jakarta ini berada di Jalan Bulaksari RT.10 RW.09 No.41 Kel.Kalisari, Kec.Pasar Rebo, Jakarta Timur. Saat ini Kepala Madrasah dari MIN 18 Jakarta adalah bapak Muhimin, S.Ag. Jumlah siswa Min 18 Jakarta adalah 480 dengan jumlah guru 26 orang, staf tata usaha 4 orang, pustakawan 1 orang, keamanan 2 orang dan kebersihan 3 orang. Madrasah Ibtidaiyah Negeri 18 Jakarta memiliki sepuluh ruang kelas (kelas 1 dan 2 paralel), satu perpustakaan, satu lab komputer, satu ruang UKS, satu koperasi dan mushola.

Strategi pemasaran sangatlah diperlukan dalam memperoleh tujuan dari suatu organisasi. Bagi lembaga pendidikan strategi pemasaran yang tepat dapat membuat reputasinya sebagai penyelenggara jasa pendidikan menjadi baik di mata stakeholder. Salah satu strategi pemasaran yang biasa digunakan adalah bauran pemasaran (marketing mix). Dalam teori pemasaran sederhana, dibedakan antara marketing mix produk jasa dan marketing mix produk barang. Menurut (Armstrong \& Kotler, 2002) marketing mix produk barang mencakup 4P yaitu, Product, Price, Place dan Promotion. Sedangkan marketing mix untuk produk jasa ditambah dengan 3P, yaitu, People, Process dan Physical Evidence. Tujuh macam variable (7P) yang mempengaruhi reputasi penyelenggara jasa pendidikan. Disamping Bauran pemasaran yang 7P tadi, citra merek (brand Image) juga berperan dalam mempengaruhi reputasi penyelenggara jasa pendidikan. Brand image sangat penting dalam mengevaluasi pelayanan karena merupakan filter yang dapat mempengaruhi persepsi peminat untuk memilih Madrasah Ibtidaiyah Negeri 18 Jakarta untuk pendidikan anaknya. Dalam industri pendidikan yang kompetitif, pengaruh citra merek terhadap sikap dan perilaku pengguna sekolah menjadi masalah yang sangat penting.

\section{Bauran Pemasaran Jasa}

Menurut (Hurriyati, 2013) definisi bauran pemasaran merupakan unsur-unsur pemasaran yang saling terkait, dibaurkan, diorganisir dan digunakan dengan tepat sehingga perusahaan dapat mencapai tujuan pemasaran dengan efektif sekaligus memuaskan kebutuhan dan keinginan konsumen. Sedangkan (Zeithaml, Bitner, \& Gremler, 2012) menyatakan bahwa konsep bauran pemasaran tradisional (tradisional marketing mix) terdiri dari 4P, yaitu : produk (produc), harga (price), tempat/lokasi (place) dan promosi (promotion). Sementara itu, untuk pemasaran jasa perlu bauran pemasaran yang diperluas (expanded marketing mix for service) dengan penambahan unsur non-tradisional marketing mix, yaitu : orang (people), fasilitas fisik (physical evidence) dan proses (process), sehingga menjadi tujuh unsur.

Menurut (Armstrong \& Kotler, 2005) menyatakan bahwa "Bauran Pemasaran (marketing mix) adalah seperangkat alat pemasaran yang digunakan perusahaan untuk terus-menerus mencapai tujuan pemasarannya di pasar sasaran, alat-alat pemasaran tersebut diklasifikasikan menjadi empat kelompok yang luas yang disebut "empat P": Produk (product), harga (price), tempat (place), dan promosi (promotion). Pendekatan pemasaran 4P ini berhasil dengan baik untuk barang, tetapi untuk bisnis jasa perlu ditambahkan elemen-elemen tambahan. Booms dan Bitmer dalam (Armstrong \& Kotler, 2005) mengusulkan 3P tambahan untuk pemasaran jasa yaitu: orang (people), bukti fisik (physical evidence), dan proses (process). Karena sebagian besar jasa diberikan oleh orang, pemilihan, pelatihan, dan motivasi karyawan dapat menghasilkan perbedaan yang sangat besar dalam kepuasan pelanggan. Perusahan-perusahan juga mencoba memperlihatkan mutu jasanya melalui bukti fisik dan dapat memilih diantara berbagai proses yang berbeda-beda untuk menyerahkan jasanya. Menurut (Kotler \& Keller, 2009) didefinisikan sebagai berikut:

a. Produk

Produk adalah segala sesuatu yang dapat ditawarkan kepada pasar untuk memuaskan suatu keinginan atau kebutuhan konsumen. Produk dapat berupa sub kategori yang menjelaskan dua jenis seperti barang dan jasa yang ditujukan kepada target pasar.

b. Harga

Harga adalah sejumlah uang yang mempunyai nilai tukar untuk memperoleh keuntungan dari memiliki atau menggunakan suatu produk atau jasa. Harga merupakan bauran pemasaran yang bersifat fleksibel di mana suatu harga akan stabil dalam jangka waktu tertentu tetapi dalam seketika harga dapat meningkat atau menurun yang terdapat pada pendapatan dari hasil penjualan.

c. Tempat/distribusi

Tempat merupakan berbagai kegiatan yang dilakukan oleh perusahaan untuk membuat produknya mudah diperoleh dan tersedia pada konsumen sasaran. Distrubusi memiliki peranan yang sangat penting dalam membantu perusahaan guna memastikan produknya. Hal ini dikarenakan tujuan dari distribusi adalah menyediakan barang dan jasa yang dibutuhkan dan diinginkan oleh konsumen pada waktu dan tempat yang tepat.

d. Promosi

Promosi adalah semua kegiatan yang dilakukan perusahaan untuk mengkomunikasikan dan mempromosikan produknya kepada pasar sasaran. 
e. Orang

People menurut Kotler yaitu proses seleksi, pelatihan, dan pemotivasian karyawan yang nantinya dapat digunakan sebagai pembedaan perusahaan dalam memenuhi kepuasan pelanggan.

f. Proses

Proses merupakan bentuk kegiatan yang dilakukan untuk memasarkan produk barang atau jasa kepada calon pelanggan. Proses yaitu semua prosedur aktual, mekanisme dan aliran aktivitas dengan mana jasa disampaikan yang merupakan sistem penyajian atas operasi jasa (Boom dan Bitner yang dikutip oleh Alma (2000:234).

g. Bukti fisik

Bukti fisik menurut Philip Kotler yaitu bukti yang dimiliki oleh penyedia jasa yang ditujukan kepada konsumen sebagai usulan nilai tambah konsumen. Bukti fisik merupakan wujud nyata yang ditawarkan kepada pelanggan ataupun calon pelanggan.

Sehingga dari definisi-definisi tersebut, disimpulkan bauran pemasaran jasa adalah seperangkat alat pemasaran (7P) yang diorganisir dan digunakan dengan tepat, guna mencapai tujuan dari perusahaan.

\section{Citra Merek}

Citra merek (brand image) dapat dianggap sebagai jenis asosiasi yang muncul dalam benak konsumen ketika mengingat suatu merek tertentu. Asosiasi tersebut secara sederhana dapat muncul dalam bentuk pemikiran atau citra tertentu yang dikaitkan dengan suatu merek, sama halnya ketika kita berpikir tentang orang lain. Asosiasi ini dapat dikonseptualisasi berdasarkan jenis, dukungan, kekuatan, dan keunikan. Jenis asosiasi merek meliputi atribut, manfaat dan sikap. Atribut terdiri dari atribut yang berhubungan dengan produk misalnya desain, warna, ukuran dan atribut yang tidak berhubungan dengan produk, misalnya harga, pemakai dan citra penggunaan. Sedangkan menurut (Shimp, 2003) manfaat adalah mencakup manfaat secara fungsional, manfaat secara simbolis dan manfaat berdasarkan pengalaman. (Kotler \& Keller, 2009) menjelaskan bahwa citra adalah cara masyarakat mempersepsi (memikirkan) perusahaan atau produknya. Sedangkan (Keller, 2003) mengatakan bahwa citra merek sebagai persepsi atau kesan tentang suatu merek yang direfleksikan oleh sekumpulan asosiasi yang menghubungkan pelanggan dengan merek dalam ingatannya. Jadi, menurut (Hribar \& Nichols, 2007) citra merek merupakan apa yang konsumen gambarkan dan pikirkan.

Saat perbedaan dan keunggulan merek dihadapkan dengan merek lain, muncullah posisi merek. Pada dasarnya sama dengan proses persepsi, karena citra terbentuk dari persepsi yang telah terbentuk lama. Setelah melalui tahap yang terjadi dalam proses persepsi, kemudian dilanjutkan pada tahap keterlibatan konsumen. (Sutisna \& Prawita, 2001) menjelaskan bahwa manfaat brand image ada tiga, yaitu:

a. Konsumen dengan citra yang positif terhadap suatu merek, lebih mungkin untuk melakukan pembelian,

b. Perusahaan dapat mengembangkan lini produk dengan memanfaatkan citra positif yang telah terbentuk terhadap merek produk lama, dan

c. Kebijakan family branding dan leverage branding dapat dilakukan jika citra produk yang telah ada positif.

Menurut (Biel, 1992), Citra merek memiliki 3 (tiga) variabel pendukung, yaitu:

a. Citra perusahaan (corporate image), yaitu sekumpulan asosiasi yang dipersepsikan konsumen terhadap perusahaan yang membuat suatu produk atau jasa. Dalam penelitian ini citra pembuat meliputi: popularitas, kredibilitas serta jaringan perusahaan,

b. Citra pemakai (user image), yaitu sekumpulan asosiasi yang dipersepsikan konsumen terhadap pemakai yang menggunakan suatu barang atau jasa. Meliputi : pemakai itu sendiri, gaya hidup/kepribadian, serta status sosialnya,

c. Citra Produk (product image), yaitu sekumpulan asosiasi yang dipersepsikan konsumen terhadap suatu produk. Meliputi artibut produk tersebut, manfaat bagi konsumen, penggunanya, serta jaminan.

Dari beberapa pengertian tersebut dapat diketahui bahwa citra merek merupakan aspek yang cukup menjadi pertimbangan konsumen dalam melakukan pembelian. Sehingga dari definisi-definisi di atas maka dapat disimpulkan bahwa citra merek merupakan suatu persepsi yang diberikan konsumen terhadap merek perusahaan yang ada dalam ingatan konsumen.

\section{Reputasi Perusahaan}

Reputasi adalah suatu nilai yang diberikan kepada individu, institusi atau negara. Reputasi tidak bisa diperoleh dalam waktu singkat karena harus dibangun bertahun-tahun untuk menghasilkan sesuatu yang bisa dinilai oleh publik. Menurut (Basya \& Sati, 2006) reputasi juga baru bertahan dan sustainable apabila konsistennya perkataan dan perbuatan. Reputasi perusahaan menurut Fombrun dalam (Cempakasari \& Yoestini, 2003) merupakan cara pandangan atau persepsi atas perusahaan oleh orang-orang baik yang berada di dalam ataupun di luar perusahaan. Pengertian tersebut mendapat dukungan dari Miles dan Covin dalam (Cempakasari \& Yoestini, 2003) bahwa salah satu perhatian itu adalah customer atau pelanggan dan tenaga penjual disamping yang lainnya seperti pemilik saham, 
masyarakat, bank dan rekan atau mitra kerja. Reputasi bagi perusahaan merupakan suatu intangible asset atau goodwill perusahaan yang memiliki pengaruh positif pada penilaian pasar atas perusahaan.

Menurut pendapat Doney dan Cannon dalam (Cempakasari \& Yoestini, 2003) bahwa reputasi perusahaan merupakan keterkaitan perusahaan dengan sejarah atau riwayat perusahaan terutama atas dasar aktivitas usaha dengan pihak lain. Pada penelitian sebelumnya (Barich \& Kotler, n.d.) menunjukkan bahwa reputasi perusahaan, sangat berperan dalam upaya untuk menimbulkan minat beli dan aktivitas pembelian oleh konsumen. Selain itu, reputasi yang baik juga dapat digunakan sebagai suatu strategi untuk meningkatkan profitabilitas. (Nguyen \& Leblanc, 2001) menyimpulkan bahwa reputasi merupakan indikator yang efektif untuk memprediksi outcome dari proses produksi jasa dan kemampuan perusahaan untuk memenuhi keinginan konsumen/nasabah. Reputasi merupakan hasil dari aktivitas perusahaan dimasa lalu dan dapat dilihat sebagai cermin dari sejarah perusahaan dalam mengkomunikasikan kualitas jasa dan produknya pada konsumen dibandingkan dengan pesaingnya. Menurut (Fombrun \& Shanley, 1990) reputasi juga dapat merefleksikan pikiran dan perasaan stakeholders tentang perusahaan. Sedangkan menurut (Barney, 1991), jika dikaitkan dengan sumber daya, maka reputasi merupakan aset yang sangat berharga yang dapat meningkatkan profit perusahaan sekaligus hambatan bagi pesaing untuk melakukan imitasi. Reputasi perusahaan dapat dibedakan dalam dua hal yaitu: Reputasi meningkatkan kepercayaan dan Reputasi Brand untuk meningkatkan kepuasan pelanggan.

Sehingga dari definisi-definisi tersebut di atas dapat disimpulkan bahwa reputasi adalah hasil refleksi yang diberikan konsumen akibat aktivitas yang dilakukan perusahaan di masa lampau.

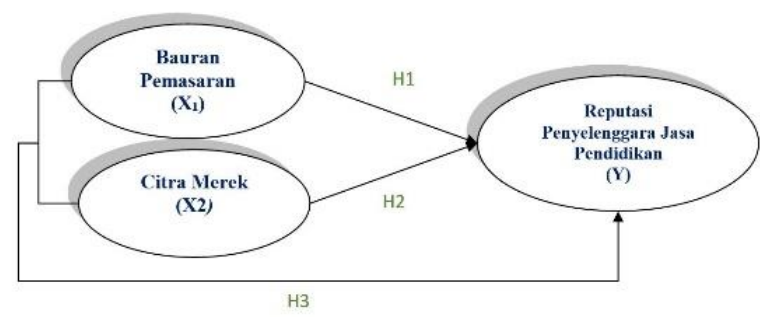

Gambar 1. Kerangka Pemikiran

\section{METODOLOGI PENELITIAN}

Penelitian ini bertujuan untuk mengetahui besarnya pengaruh bauran pemasaran jasa dan citra merek terhadap reputasi penyelenggara jasa pendidikan di Madrasah Ibtidaiyah Negeri 18 Jakarta.
Metode penelitian yang digunakan adalah kuantitatif dengan jenis penelitian model survei, yaitu suatu rancangan penelitian dengan tujuan melakukan pengujian cermat terhadap objek penelitian berdasarkan kondisi tertentu. Informasi diperoleh dari responden melalui wawancara dan kuesioner dengan sampel tertentu, dimana survei dilakukan dengan menyebarkan kuesioner kepada orang tua/wali murid yang memilih Madrasah Ibtidaiyah Negeri 18 Jakarta untuk anaknya. Teknik pengambilan sampel dalam penelitian ini secara simple random sampling yaitu sebanyak 83 orang. Kuisioner merupakan sekumpulan pertanyaan tertutup dimana responden dipersilahkan menjawab pertanyaan dengan jawaban berkisar antara Sangat Setuju (5), Setuju (4), Raguragu (3), Tidak Setuju (2), Sangat Tidak Setuju (1). Jawaban responden diberi nilai dengan skala Likert. Berdasarkan gambar 1. maka hipotesis dari penelitian ini adalah :

1. H1 : Terdapat pengaruh signifikan variabel Bauran Pemasaran Jasa $\left(\mathrm{X}_{1}\right)$ terhadap Reputasi Penyelenggara Jasa Pendidikan (Y) pada Madrasah Ibtidaiyah Negeri 18 Jakarta.

2. H2 : Terdapat pengaruh signifikan variabel Citra Merek $\left(\mathrm{X}_{2}\right)$ terhadap Reputasi Penyelenggara Jasa Pendidikan (Y) pada Madrasah Ibtidaiyah Negeri 18 Jakarta.

3. H3 : Terdapat pengaruh signifikan variabel Bauran Pemasaran Jasa $\left(\mathrm{X}_{1}\right)$ dan variabel Citra Merek $\left(\mathrm{X}_{2}\right)$ secara bersama-sama terhadap Reputasi Penyelenggara Jasa Pendidikan (Y) pada Madrasah Ibtidaiyah Negeri 18 Jakarta.

\section{HASIL DAN PEMBAHASAN}

\section{Pengujian Hipotesis}

Berdasarkan uji t pada taraf $1 \%$ seperti terlihat pada Tabel 1. bahwa Bauran Pemasaran Jasa berpengaruh secara signifikan terhadap Reputasi Penyelenggaraan Jasa Pendidikan dengan keabsahan sebesar 99\% dimana nilai $t_{\text {hitung }}>t_{\text {tabel }}$ yaitu $12.772>$ 2,372 . Nilai $t_{\text {tabel }}$ pada taraf signifikan $1 \%$ dengan $\mathrm{db}=$ 81 adalah 2,372. Sehingga dapat disimpulkan bahwa memang terdapat pengaruh positif dan signifikan antara Bauran Pemasaran Jasa terhadap Reputasi Penyelenggara Jasa di MIN 18 Jakarta. Dengan demikian hipotesis 1 terbukti.

Tabel 1. Koefisien Regresi $\mathrm{X}_{1}$ terhadap $\mathrm{Y}$

\begin{tabular}{|c|l|l|l|l|l|l|}
\hline \multicolumn{2}{|c|}{} & \multicolumn{2}{|c|}{$\begin{array}{c}\text { Unstandardized } \\
\text { Model }\end{array}$} & $\begin{array}{c}\text { Standar } \\
\text { dized } \\
\text { Coefficients } \\
\text { Coeffici } \\
\text { ents }\end{array}$ & \multirow{2}{*}{$\mathrm{t}$} & Sig. \\
\cline { 2 - 5 } & B & $\begin{array}{l}\text { Std. } \\
\text { Error }\end{array}$ & Beta & & \\
\hline \multirow{2}{*}{1} & (Constant) & 15.85 & 2.707 & & 5.857 & 0 \\
\cline { 2 - 6 } & skor_bauran & 0.777 & 0.061 & 0.817 & 12.772 & 0 \\
\hline
\end{tabular}

Sumber : Data yang diolah (2015) 
Tabel 2. Koefisien Determinan (Adjusted R Square) $X_{1}$ terhadap Y

\begin{tabular}{|l|l|l|l|l|}
\hline Model & $R$ & $\begin{array}{l}R \\
\text { Square }\end{array}$ & $\begin{array}{l}\text { Adjusted } \\
R \\
\text { Square }\end{array}$ & $\begin{array}{l}\text { Std. Error } \\
\text { of the } \\
\text { Estimate }\end{array}$ \\
\hline 1 & $.817^{\mathrm{a}}$ & 0.668 & 0.664 & 4.527 \\
\hline
\end{tabular}

Sumber : Data yang diolah (2015)

Terlihat pada Tabel 2. bahwa nilai $\mathrm{R}^{2}$ tersebut menunjukkan bahwa variabel Bauran Pemasaran Jasa memberikan pengaruh terhadap variabel Reputasi Penyelenggara Jasa Pendidikan sebesar 66,4\%, sedangkan sisanya sebesar $33,6 \%$ ditentukan oleh faktor lain yang belum diketahui.

Sedangkan untuk Citra Merek setelah dilakukan uji t pada taraf $1 \%$ dihasilkan bahwa Citra Merek berpengaruh secara signifikan terhadap Reputasi Penyelenggaraan Jasa Pendidikan dengan keabsahan sebesar $99 \%$ dimana nilai $t_{\text {hitung }}>t_{\text {tabel }}$ yaitu $8,383>2,372$. Nilai tabel pada taraf signifikan $1 \%$ dengan $\mathrm{db}=81$ adalah 2,372. Seperti yang terlihat pada Tabel 3. Hal ini dapat disimpulkan bahwa memang terdapat pengaruh positif dan signifikan antara Citra Merek MIN 18 Jakarta terhadap Reputasi Penyelenggara Jasa di MIN 18 Jakarta. Dengan demikian hipotesis 2 terbukti.

Tabel 3. Koefisien Regresi ( $\mathrm{X}_{2}$ terhadap $\left.\mathrm{Y}\right)$

\begin{tabular}{|c|l|l|l|l|l|l|}
\hline \multicolumn{2}{|c|}{ Model } & \multicolumn{2}{|c|}{$\begin{array}{c}\text { Unstandardized } \\
\text { Coefficients }\end{array}$} & $\begin{array}{c}\text { Standar } \\
\text { dized } \\
\text { Coeffici } \\
\text { ents }\end{array}$ & t & Sig. \\
\cline { 2 - 7 } & B & $\begin{array}{l}\text { Std. } \\
\text { Error }\end{array}$ & Beta & & \\
\hline \multirow{2}{*}{1} & (Constant) & 20.921 & 3.506 & & 5.967 & 0 \\
\cline { 2 - 7 } & $\begin{array}{l}\text { skor_citra_ } \\
\text { merek }\end{array}$ & 0.623 & 0.074 & 0.682 & 8.383 & 0 \\
\hline
\end{tabular}

Sumber : Data yang diolah (2015)

Tabel 4. Koefisien Determinan (Adjusted R Square) $\mathrm{X}_{2}$ terhadap Y

\begin{tabular}{|l|l|l|l|l|}
\hline Model & $R$ & $R$ Square & $\begin{array}{l}\text { Adjusted } \\
R \text { Square }\end{array}$ & $\begin{array}{l}\text { Std. Error of } \\
\text { the Estimate }\end{array}$ \\
\hline 1 & $.682^{\mathrm{a}}$ & 0.465 & 0.458 & 5.751 \\
\hline
\end{tabular}

Sumber : Data yang diolah (2015)
Terlihat pada Tabel 4. bahwa nilai $\mathrm{R}^{2}$ tersebut menunjukkan bahwa variabel Citra Merek memberikan pengaruh terhadap variabel Reputasi Penyelenggara Jasa Pendidikan sebesar 45,8\%, sedangkan sisanya sebesar $54,2 \%$ ditentukan oleh faktor lain yang belum diketahui.

Tabel 5. Adjusted R Square $X_{1}$ dan $X_{2}$ terhadap $Y$

\begin{tabular}{|l|l|l|l|l|}
\hline Model & $R$ & $R$ Square & $\begin{array}{l}\text { Adjusted } \\
R \text { Square }\end{array}$ & $\begin{array}{l}\text { Std. Error of } \\
\text { the Estimate }\end{array}$ \\
\hline 1 & $.842^{\mathrm{a}}$ & 0.709 & 0.702 & 4.264 \\
\hline
\end{tabular}

Sumber : Data yang diolah (2015)

Namun jika secara bersama-sama variabel Bauran Pemasaran Jasa dan variabel Citra Merek mampu mempengaruhi variabel Reputasi Penyelenggara Jasa Pendidikan sebesar 70,2\% sedangkan sisanya sebesar $29,8 \%$ ditentukan oleh faktor lain seperti yang terlihat pada tabel 5. di atas.

Berdasarkan penjelasan-penjelasan di atas, disimpul-kan variabel Bauran Pemasaran Jasa memiliki pengaruh terhadap variabel Reputasi Penyelenggara Jasa Pendidikan di MIN 18 Jakarta sebesar $66,4 \%$ sisanya $33,6 \%$ oleh faktor lain dan variabel Citra Merek memiliki pengaruh terhadap variabel Reputasi Penyelenggara Jasa Pendidikan di MIN 18 Jakarta sebesar 45,8\% sisanya oleh faktor lain. Namun jika bersama-sama yaitu variabel Bauran Pemasaran Jasa dan Citra Merek terhadap Reputasi Penyelenggara Jasa Pendidikan pengaruhnya menjadi lebih besar yaitu sebesar 70,2\% dibandingkan jika sendiri-sendiri. Dengan demikian hipotesis 3 terbukti.

\section{KESIMPULAN}

Kesimpulan yang dapat diambil dari hasil penelitian ini adalah:

1. Bauran Pemasaran Jasa berpengaruh terhadap Reputasi Madrasah Ibtidaiyah Negeri 18 Jakarta dengan ketelitian 99\%, karena $\mathrm{t}_{\text {hitung }}>\mathrm{t}_{\text {tabel }}$ (12,772>2,372). Besar pengaruh Bauran Pemasan Jasa adalah sebesar 66,4\%, sedangkan sisanya sebesar 33,6\% ditentukan oleh faktor lain yang belum diketahui.

2. Citra Merek berpengaruh terhadap Reputasi Madrasah Ibtidaiyah Negeri 18 Jakarta dengan ketelitian $99 \%$, karena $t_{\text {hitung }}>t_{\text {tabel }}(8,383>2,372)$. Besar pengaruh Citra Merek adalah sebesar $45,8 \%$, sedangkan sisanya sebesar $54,2 \%$ ditentukan oleh faktor lain. 
3. Bauran Pemasaran Jasa dan Citra Merek secara bersama-sama berpengaruh signifikan terhadap Reputasi Penyelenggaraan Jasa Pendidikan dengan ketelitian $99 \%$ karena $\mathrm{F}_{\text {hitung }}>\mathrm{F}_{\text {tabel }}$ (97,622>6,96). Besar pengaruh Bauran Pemasaran dan Citra Merek terhadap Reputasi Madrasah Ibtidaiyah Negeri 18 Jakarta adalah sebesar $70,2 \%$. sedangkan sisanya sebesar 29,8 $\%$ ditentukan oleh faktor lain.

\section{REFERENSI}

Armstrong, G., \& Kotler, P. (2002). Dasar-dasar Pemasaran. Jilid 1, Alih Bahasa Alexander Sindoro dan Benyamin Molan. Jakarta: Prenhalindo.

Armstrong, G., \& Kotler, P. (2005). Manajemen Pemasaran. Jilid 1 dan 2, diterjemahkan oleh Benyamin Molan (11th ed.). Jakarta: PT. Indeks Gramedia.

Barich, H., \& Kotler, P. (n.d.). A Framework for Marketing Image Management. Sloan Management Review.

Barney, J. (1991). Firm Resources and Sustained Competitive Advantage. Journal of Management, 17(1), 99-120. https://doi.org/10.1177/014920639101700108

Basya, M., \& Sati, I. (2006). Tantangan Indonesia Baru: Strategi dan Aktivitas Public Relations. Jakarta: BPP Perhumas.

Biel, A. L. (1992). Converting Image Into Equity. Journal of Advertising Research, (Chapter 5).

Cempakasari, D. A., \& Yoestini. (2003). Studi Mengenai Pengembangan Hubungan Jangka Panjang Perusahaan dan Pengecer. Jurnal Sains Pemasaran Indonesia, 2(No.1), 67-84. https://doi.org/http://dx.doi.org/10.14710/jspi. v2i1.67-84

Fombrun, C. J., \& Shanley, M. (1990). What Is in a Name? Reputation Building and Corporate Strategy. Academy of Management Journal, 33, 233-259.

Hribar, P., \& Nichols, D. C. (2007). The use of unsigned earnings quality measures in tests of earnings management. Journal of Accounting Research. $\quad$ https://doi.org/10.1111/j.1475679X.2007.00259.x

Hurriyati, R. (2013). Bauran Pemasaran dan Loyalitas Konsumen. Bandung: Alfabeta.

Keller, K. L. (2003). Strategic Brand Management, Second Edition (2nd ed.). New York: Prentice Hall.

Kotler, P., \& Keller, K. L. (2009). Manajemen Pemasaran. Jilid 1 dan 2, Alih Bahasa Benyamin Molan. Jakarta: Erlangga.

Nguyen, N., \& Leblanc, G. (2001). Corporate Image and Corporate Reputation in Customers' Retention Decisions in Services. Journal of Retailing and Consumer Services (Vol. 8). https://doi.org/10.1016/S0969-6989(00)000291

Shimp, T. A. (2003). Advertising, Promotion, and Other Aspects of Integrated Marketing Communications (5th ed.). New Jersey: South Western Educational Publishing.

Sutisna, \& Prawita, T. (2001). Perilaku Konsumen dan Komunikasi Pemasaran. Bandung: PT. Remaja Rosdakarya.

Zeithaml, V., Bitner, M. J., \& Gremler, D. (2012). Services Marketing (6th Edition). (M.-H. Education, Ed.) (6th ed.). New York. 